\title{
Effect of herbage allowances on biomass flows in Italian ryegrass
}

\author{
Larissa Arnhold Graminho ${ }^{*}$ (iD) Marta Gomes da Rocha ${ }^{2}$ Luciana Pötter $^{2}$ \\ Aline Tatiane Nunes da Rosa $^{3}$ Paulo Roberto Salvador ${ }^{2}$ Luiz Gonzaga do Amaral ${ }^{2}$ \\ Tuani Lopes Bergoli² (D) Lucas Munareto Cadó ${ }^{2}$
}

${ }^{1}$ Departamento de Plantas Forrageiras e Agrometeorologia, Universidade Federal do Rio Grande do Sul (UFRGS), 90040-060, Porto Alegre, RS, Brasil. E-mail: laraarnhold@hotmail.com. "Corresponding author.

${ }^{2}$ Departamento de Zootecnia, Centro de Ciências Rurais (CCR), Universidade Federal de Santa Maria (UFSM), Santa Maria, RS, Brasil.

${ }^{3}$ Instituto Federal de Educação Ciência e Tecnologia Farroupilha (IFFAR), Santa Maria, RS, Brasil.

ABSTRACT: The objective of this study was to determine the leaf tissue flows in Italian ryegrass (Lolium multiflorum Lam.), in different phenological stages, grazed by lambs, and managed under three herbage allowances (6, 9 and $12 \mathrm{~kg} \mathrm{DM/100} \mathrm{kg} \mathrm{body} \mathrm{weight} \mathrm{under} \mathrm{rotational}$ stocking method. The experimental design was completely randomized, with repeated measures arrangement. Forage allowances determined similar growth and intake flows, actual and potential utilization efficiencies of grass and they were different in the phenological stages of Italian ryegrass. The intake of leaf blade, as a percentage of body weight, was higher in the $12 \%$ herbage allowance. Considering leaf tissue flows, Italian ryegrass can be managed in forage allowances that vary between 6 and $12 \mathrm{~kg} \mathrm{DM} / 100 \mathrm{~kg}$ body weight.

Key words: intake, lambs, phenological stages, Lolium multiflorum.

Efeito de ofertas de forragem sobre o fluxo de biomassa em azevém

RESUMO: Este trabalho foi conduzido com o objetivo de determinar os fluxos de tecidos foliares em diferentes estádios fenológicos do azevém (Lolium multiflorum Lam.), pastejado por cordeiras, manejado sob três niveis de oferta de forragem (6; 9 e $12 \mathrm{~kg}$ de MS/100 kg de peso corporal), sob lotação intermitente. O delineamento experimental foi inteiramente casualizado, com medidas repetidas no tempo. Os fluxos de crescimento e consumo de lâminas foliares, as eficiencias real e potencial de utilização do pasto foram similares nas ofertas de forragem e diferentes nos estádios fenológicos do azevém. O consumo de lâminas foliares em porcentagem do peso corporal foi superior na oferta de forragem 12\%. Considerando os fluxos de tecidos foliares, o azevém pode ser manejado com ofertas de forragem que variam entre 6 a $12 \mathrm{~kg}$ de MS/100 kg de peso corporal.

Palavras-chave: consumo, cordeiras, estádios fenológicos, Lolium multiflorum.

\section{INTRODUCTION}

Research on forage farming has sought to relate plant response to management based on criteria associated with biomass abundance, such as herbage allowances (HA). By integrating information on forage mass and stocking rate, studies on HA allow us to safely evaluate animal performance in pastures (SOLLENBERGER et al., 2005).

To understand the effects of different types of management strategies on pasture dynamics and evolution, knowledge of the growth, intake, and senescence of forage species is fundamental. Thus, determination of these parameters through biomass flow technique is fundamental for the understanding of pasture ecophysiology (CONFORTIN et al., 2009).
In southern Brazil, annual ryegrass (Lolium multiflorum Lam) has great importance in livestock systems. The ryegrass is a spring-winter growth species that has high nutritional value and can be used in the efficient and economically viable production of lambs, which are animals with high nutritional requirements. The identification of the growth stage of grasses is fundamental for making decisions regarding pasture management. Progression of the phenological stage modifies the botanical and structural composition of ryegrass (SKONIESKI et al., 2011), occurring less participation of green leaves and reduction in their quality.

To evaluate biomass fluxes in ryegrass under continuous stocking, it was recommended that the canopy height be kept between 10 and 
$15 \mathrm{~cm}$ (PONTES et al., 2004). While comparing methods (rotational and continuous) and two grazing intensities (low and moderate), CAUDURO et al. (2007) verified that rotational stocking and low intensity favored growth flow and in continuous stocking with low defoliation intensity, the senescence rate was increased. In a study on ryegrass managed under three forage disappearance intensities, CONFORTIN et al. (2009) observed that in grazing, the $43.3 \%$ disappearance intensity of pre-grazing forage mass allowed a greater flow of leaf blades intake, with intermediate growth and senescence flows. SILVA et al. (2015), observed that when ryegrass is managed under different stocking rates, the leaf biomass flow is not altered.

Considering the importance of annual ryegrass in animal husbandry, studies that relate forage abundance to biomass flows are relevant, since they contribute to devising adequate strategies for the management of this forage species. The objective of this work was to evaluate the dynamics of leaf tissue flows and to characterize the ryegrass canopy structure in different phenological stages and managed under three herbage allowances in grazing with sheep under intermittent stocking.

\section{MATERIAL AND METHODS}

The experiment was carried out at the Federal University of Santa Maria (UFSM), located in the central depression region of Rio Grande do Sul, in a soil classified as Arsenic dystrophic Red Argisol. The climate of the region is humid subtropical (Cfa), according to Köppen classification. The 0.6 ha experimental area was subdivided into six plots, which constituted the experimental units. The ryegrass (Lolium multiflorum Lam) cultivar 'Common' was planted in May 2012, using 45 kg of seeds per hectare. The period of pasture use was from June to October 2012. Fertilization was done using $200 \mathrm{~kg} /$ ha of $\mathrm{N}: \mathrm{P}: \mathrm{K}$ in the ratio 05:20:20. Being $100 \mathrm{~kg}$ of $\mathrm{N} / \mathrm{ha}$ in the form of urea carried out in tree applications on the vegetation cover on $06 / 06,07 / 07$ and 18/08/2012.

Grazing occurred at an intermittent stocking density, and the animals were allowed forage at the rate 6,9 , and $12 \mathrm{~kg}$ dry matter (DM) per $100 \mathrm{~kg}$ body weight (BW), in two phenological stages of ryegrass: vegetative (06/24/2012-09/03/2012) and pre-flowering (09/04/2012), determined according to the scale proposed by MOORE et al. (1991).

The criterion to determine the interval between periods of occupation was the accumulated thermal sum (TS) of 250 degree days, equivalent to the thermal sum necessary for the successive appearance of two leaves of ryegrass (CONFORTIN et al., 2010). Plots were occupied for 12 days at a time and one grazing cycle constituted the occupation period plus the interval until the beginning of the next occupation. The thermal sum (TS) was calculated by the equation: $\mathrm{TS}=\Sigma\left(\mathrm{Mdt}-5^{\circ} \mathrm{C}\right)$ where $\mathrm{Mdt}=$ mean daily temperatures $\left({ }^{\circ} \mathrm{C}\right)$ of the period and $5{ }^{\circ} \mathrm{C}=$ value considered as base temperature of cold season species (CONFORTIN et al., 2010). In the vegetative stage, the pasture was occupied twice with 26-day intervals between each occupation. There was a 12-day interval between the vegetative and pre-flowering stages.

The animals used were 8-month-old Suffolk lambs, with an initial mean weight of $43 \pm 4.6$ $\mathrm{kg}$. The lambs had free access to water and mineral salts. Three test-lambs per plot and a variable number of control animals were used to adjust the bids.

The forage mass ( $\mathrm{kg} \mathrm{DM} / \mathrm{ha})$ was determined by means of the double sampling visual estimation technique, performed at the beginning and at the end of each grazing period. From the forage of the cuttings, the dry matter content and the participation of the botanical and structural components of the pasture were determined at the beginning and the end of the grazing cycle. Subsequently, the material was dried in a forced air circulation oven at $55^{\circ} \mathrm{C}$ until constant weight was achieved. From the proportion of leaves and stems, the leaf: stem ratio at the beginning and at the end of each grazing period was determined.

The daily forage accumulation rate was determined by the formula: $F D R=(M F 1$ (i) - MF2 $(\mathrm{i}-1)) / D$. Where: FDR $=$ forage accumulation daily rate; FM1 = pre-grazing forage mass of the grazing cycle "i"; FM2 = post-grazing forage mass of the grazing cycle " $\mathrm{i}-1$ "; $\mathrm{D}=$ number of days in the grazing interval period. The instantaneous stocking rate was determined by the relationship between body weight $(\mathrm{kg})$ of the animals and the area of the management unit occupied by the animals during the grazing period.

HA was calculated by the formula: $\mathrm{HA}=$ $((\mathrm{MF} / \mathrm{n}+\mathrm{TAD}) / \mathrm{TL}) \times 100$, where HA $=$ herbage allowances $(\%)$; MF = mean forage mass $(\mathrm{kg} / \mathrm{ha} \mathrm{DM})$ $=[($ initial $\mathrm{MF}+$ final MF $) / 2] ; \mathrm{n}=$ number of days of the grazing period (days); FDR = forage accumulation daily rate $(\mathrm{kg} / \mathrm{ha} /$ day $\mathrm{DM}) ; \mathrm{SR}=$ stocking rate of the grazing cycle (kg/ha of BW). The supply of green leaf blades was obtained by multiplying HA by the mean percentage of leaf blades in MF.

The canopy height, measured as the distance $(\mathrm{cm})$ from the soil surface to the mean leaf 
fold height, was measured daily during the grazing period and every 3 days during the grazing interval. For the determination of morphogenetic and structural characteristics, the technique of marked tillers (70 tillers evaluated by HA) was used. The length, appearance, and number of leaf blades, in addition to their condition (intact or defoliated, presence or absence of senescence,) and pseudostem height were measured daily during the grazing period and every 3 or 4 days at intervals between grazing. The depth of leaf blades was calculated by subtracting the pseudostem height from canopy height. During the grazing cycles, the population density of live ryegrass tillers (tillers $/ \mathrm{m}^{2}$ ) was counted in three fixed areas of $0.0625 \mathrm{~m}^{2}$ per plot.

Senescence rates, foliar leaf elongation in $\mathrm{cm} /$ degree day were calculated by the ratio between the elongation or mean tiller senescence between two consecutive evaluations and the accumulated thermal sum in the same period. Flows of growth (FGro), senescence (FSen), and intake (FIn) were determined by equations described by PONTES et al. (2004). FIn was calculated for each period of occupation of plots, while FGro and FSen were calculated for the whole period. The actual efficiency of pasture utilization (AEU) was calculated using the equation $\mathrm{AEU}=\mathrm{FIn} / \mathrm{FGro}$, and the potential efficiency of pasture utilization (PEU) was calculated using the equation $\mathrm{PEU}=1-(\mathrm{FSen} / \mathrm{FGro})$ (LOUAULT et al., 1997). For net balance (NB) determination, the equation NB $=[$ FGro $-($ FSen + FIn $)]$ was used. For the determination of leaf blade intake (in \% of BW), the mean flow of intake was multiplied by 100 and divided by the stocking rate.

The experimental design was completely randomized, with measures repeated in time and use of two area replications. After conducting normality test, the data were analyzed by a mixed model, considering the fixed effect of HA, phenological stages ('vegetative' and 'pre-flowering'), and their interactions, and the random effects of the residue and of nested plots in the HA. The selection of the best matrix structure was made based on the Bayesian information-BIC criterion. When differences were detected, the means were compared by the lsmeans procedure with $10 \%$ probability. The variables were also submitted to Pearson's correlation analysis. The statistical package SAS version 9.2 was used (SAS, 2002).

\section{RESULTS AND DISCUSSION}

The HA values observed were close to the values required by the experimental protocol, being 12.6 (12), 8.8 (9), and 6.6 (6) \%. There was no interaction $(\mathrm{P}=0.6907) \mathrm{HA} \times$ phenological stage for the variable instantaneous stocking rate. The stocking rate was higher $(\mathrm{P}=0.0334)$ in the $6 \% \mathrm{HA}(3436 \mathrm{~kg} /$ ha of body weight $(\mathrm{BW})$ ); intermediate in the $9 \%$ HA $(2382 \mathrm{~kg} / \mathrm{ha}$ of BW), and lower in the $12 \% \mathrm{HA}$ $(1791 \mathrm{~kg} / \mathrm{ha} \mathrm{BW})$. The instantaneous stocking rate in the vegetative stage was $2014 \mathrm{~kg} / \mathrm{ha}$ of BW, being $36 \%$ lower than the stocking rate observed at the preflowering stage ( $3125 \mathrm{~kg} /$ ha of $\mathrm{BW} ; \mathrm{P}=0.0018$ ).

There was no interaction between HA and phenological stage for canopy height, leaf emergence rate, forage mass in pre and post-grazing, allowances of leaf blades, and population density of ryegrass tiller (Table 1). The height of the canopy was higher in the $12 \% \mathrm{HA}$, being $4.9 \mathrm{~cm}$ higher than the mean height $(7.8$ $\mathrm{cm}$ ) observed in plots managed with 6 or $9 \%$ HA, the latter two not differing significantly from each other. In the $12 \% \mathrm{HA}$, the canopy height was within the range of 10-15 cm, recommended by PONTES et al. (2004), which would optimize ryegrass biomass flows.

Leaf blade emergence rate (LER) was similar in the 6 and 9\% HA (0.0095 leaves/degree day) being $26 \%$ higher than that observed in the $12 \%$ HA (Table 1). LER was similar in the phenological stages of ryegrass (0.0085 leaf/degree day; table 1$)$. The pseudostem height in the $12 \%$ HA was 7.5 $\mathrm{cm}$, being $37 \%$ higher than the height observed in the 6 and 9\% HA (Table 1), the latter two being similar to each other. The pseudostem height in the pre-flowering stage was greater than the height observed in the vegetative stage (Table 1). There was a negative correlation $(\mathrm{r}=-0.77 ; \mathrm{P}=0.0119)$ between LER and pseudostem height, which may explain the differences in LER in the different HA, since the pseudostem length is the distance that an elongating leaf must travel to emerge (PENA et al., 2009). Thus, the distance traveled by the leaves until their appearance in the HA 6 and 9\% was lower than the distance traveled in the $12 \% \mathrm{HA}$, allowing the appearance of more leaves per degree day in the lower HA. In the phenological stages, the pseudostem height variations were not enough to alter LER.

Pre- and post-grazing mass values of foliar leaf mass and pseudostem (Table 1) were similar in all HA $(\mathrm{P}>10)$. The transition from vegetative stage to ryegrass pre-flowering resulted in pre-and postgrazing forage masses that were 43 and $38 \%$ higher, respectively (Table 1), which may have been caused by a $72 \%$ increase in mean stems, from 241 to $875 \mathrm{~kg}$ $\mathrm{DM} / \mathrm{ha}$, from the vegetative stage to pre-flowering, without difference in the mean mass of leaf blades. The stem mass increase showed a correlation with pseudostem length $(\mathrm{r}=0.68 ; \mathrm{P}=0.0114)$, which was 
Table 1 - Canopy height (CH), leaf emergence rate (LER), pre (PrMG) and post mass grazing (PtMG), allowance of leaf blades (AL), pseudostem height $(\mathrm{PH})$, tiller population density (TPD) of ryegrass managed under different forage (HA) and phenological stages (PS)

\begin{tabular}{|c|c|c|c|c|c|c|c|}
\hline & $\mathrm{CH}^{4}$ & LER $^{5}$ & $\operatorname{PrMG}^{6}$ & $\mathrm{PtMG}^{6}$ & $\mathrm{AL}^{7}$ & $\mathrm{PH}^{4}$ & $\mathrm{TPD}^{8}$ \\
\hline \multicolumn{8}{|c|}{ 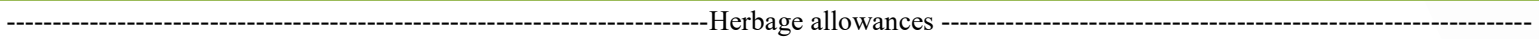 } \\
\hline $6 \%$ & $6,9 \mathrm{~b}$ & $0,010 \mathrm{a}$ & 2031 & 797 & $1,9 \mathrm{~b}$ & $4,5 b$ & $4633 a$ \\
\hline $9 \%$ & $8,7 \mathrm{~b}$ & $0,009 \mathrm{a}$ & 1931 & 1275 & $2,4 \mathrm{~b}$ & $5,0 \mathrm{~b}$ & $4423 a$ \\
\hline $12 \%$ & $12,7 \mathrm{a}$ & $0,007 b$ & 2248 & 1783 & $3,4 a$ & $7,5 \mathrm{a}$ & $3655 b$ \\
\hline \multicolumn{8}{|c|}{ 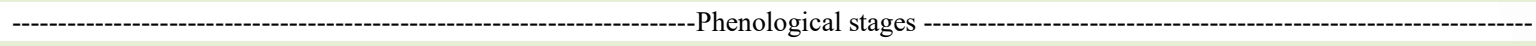 } \\
\hline Veg $^{1}$ & 9,7 & 0,008 & $1504 b$ & $987 b$ & $3,8 \mathrm{a}$ & $5,0 \mathrm{~b}$ & 4260 \\
\hline Pre-flor ${ }^{2}$ & 9,1 & 0,009 & $2636 \mathrm{a}$ & $1584^{\mathrm{a}}$ & $1,3 \mathrm{~b}$ & $7,3 \mathrm{a}$ & 4220 \\
\hline \multicolumn{8}{|c|}{ 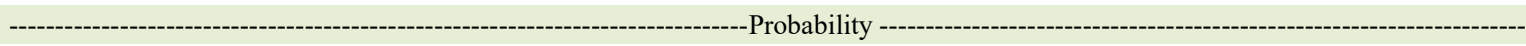 } \\
\hline Allowances & 0,0556 & 0,0483 & 0,6466 & 0,1686 & 0,0365 & 0,1098 & 0,0931 \\
\hline PS & 0,5540 & 0,1281 & 0,0020 & 0,0276 & $<0,0001$ & 0,0002 & 0,8758 \\
\hline Interaction & 0,2717 & 0,1318 & 0,4848 & 0,3314 & 0,1936 & 0,2030 & 0,3571 \\
\hline $\mathrm{CV}^{3}$ & 14,8 & 8,1 & 9,0 & 4,8 & 11,7 & 8,1 & 9,7 \\
\hline
\end{tabular}

Values followed by letters in the columns differ from each other by the lsmeans test at the $10 \%$ level of significance. ${ }^{1}$ Phenological stage vegetative and pre-flowering; ${ }^{2}$ Phenological stage pre-flowering; ${ }^{3}$ Coefficient of variation $(\%) ;{ }^{4} \mathrm{~cm} ;{ }^{5} \mathrm{leaf} / \mathrm{degree} \mathrm{day;}{ }^{6} \mathrm{~kg} \mathrm{DM} / \mathrm{ha} ;{ }^{7} \mathrm{~kg}$ of leaf blades/hectare/day; ${ }^{8}$ tiller $\mathrm{m}^{2}$.

higher in the pre-flowering period, during which ryegrass internodes elongate.

In HA, the change in forage mass structure was manifested in differential leaf blades supply (LBS). The highest LBS was observed in 12\% HA, being 1.25 percentage points higher than LBS in the plots with 6 or $9 \%$ HA, the latter two not differing from each other. At the vegetative stage, the LBS was 4.5 times higher than the LBS observed at ryegrass pre-flowering. (Table 1). The lowest LBS in the 6 and $9 \%$ HA may have been the result of an observed higher stocking rate and also greater accessibility to grazing of this component.

Tiller population density (TPP) was similar in 6 and 9\% HA (4533 tiller $\mathrm{m}^{2}$ ), being 19\% higher than the TPP observed in $12 \%$ HA (Table 1). The $12 \%$ HA higher canopy (Table 1) probably caused less light incidence on ryegrass basal buds, and consequently, the yield of tillers was lower in this HA because greater light incidence at the plant base stimulates tillering (SBRISSIA; DA SILVA, 2008). Contrarily, TPP was similar (Table 1) in the phenological stages, with canopy height being similar in the vegetative and pre-flowering stages of ryegrass.

There was no $\mathrm{HA} \times$ phenological stage interaction for the FGro of leaf blades (Figure 1, $\mathrm{P}=0.2066)$, which was similar in all $\mathrm{HA}(47.6 \mathrm{~kg}$ $\mathrm{DM}, \mathrm{P}=0.4158)$. The FGro of leaf blades in the ryegrass vegetative stage $(60.3 \mathrm{~kg} \mathrm{DM}$ of leaf blades/ ha/day, $\mathrm{P}=0.0045$, figure 1) was $41.4 \%$ higher than the observed FGro during pre-flowering $(35.3 \mathrm{~kg}$ DM of leaf blades/ha/day). During pre-flowering, floral induction possibly decreased the FGro. During elongation of the apical meristem of grasses, the plant ceases leaf production and all nutrient allocation to older leaves, and the photo-assimilates produced are reserved for internodal elongation and reproductive structure formation (SALVADOR et al., 2014).

The different HA did not cause enough structural changes in the canopy to change leaf blades flow $(48.7 \mathrm{~kg}$ of leaf blades/hectare/day, figure 1, $\mathrm{P}=0.2206$ ). In the vegetative stage, FIn was $60.9 \mathrm{~kg}$ DM of leaf blades/ha/day, $39.4 \%$ higher than that observed in the pre-flowering stage $(36.6 \mathrm{~kg} \mathrm{DM}$ of leaf blades/ha/day, $\mathrm{P}=0.0076$, figure 1). FIn of leaf blades correlated with leaf: stem ratio (LSR; $\mathrm{r}=0.60 \mathrm{P}=0.0323$ ). According to Zanini et al. (2012), nutrient intake and animal performance are affected by components associated with the architecture and morphological and botanical composition in the pasture, as well as changes in leaf blades supply and leaf: stem ratio occurring during pre- flowering, which possibly results in a lower FIn of leaf blades. Also, during pre-flowering, the lower FIn may have occurred because of the increase in stem mass, since stems present greater resistance to animal herbivory, which is the main factor responsible for changes in the canopy structure of grasses (SALVADOR, et. al., 2016). 


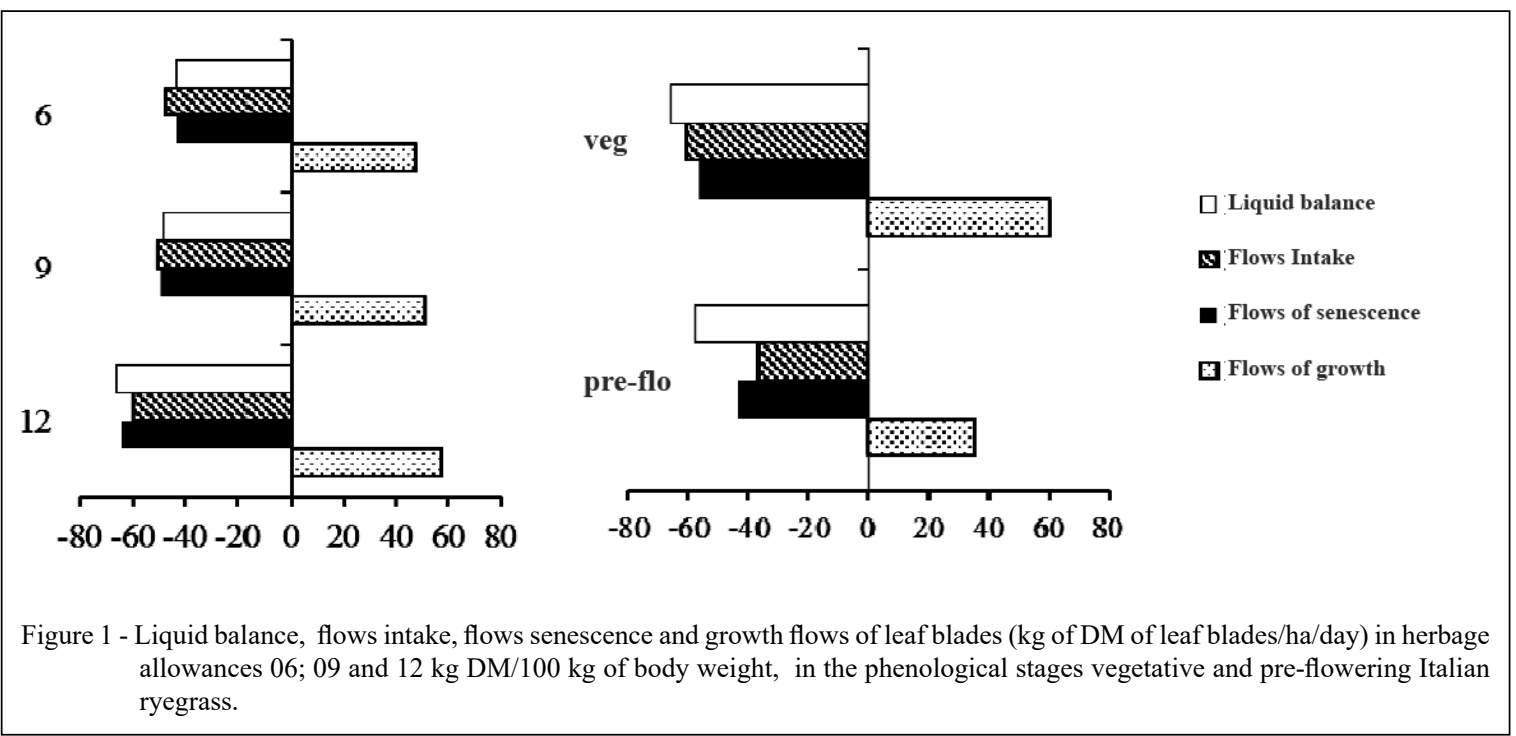

There was interaction of HA $\times$ phenological stages for leaf $F S e n(P=0.0602)$. In the vegetative stage of ryegrass, regardless of HA, leaf FSen was $56.2 \mathrm{~kg} /$ ha/day leaf blades DM $(\mathrm{P}=0.1446)$. This flow, in the pre-flowering stage, varied depending on the HA $(\mathrm{P}=0.0447)$. FSen was higher $(67.7 \mathrm{~kg} / \mathrm{ha} /$ day leaf blades DM), intermediate $(40.1 \mathrm{~kg} / \mathrm{ha} /$ day leaf blades $\mathrm{DM})$, and lower $(21.7 \mathrm{~kg} / \mathrm{ha} /$ day leaf blades $\mathrm{DM})$ in the $12 \%, 9 \%$, and $6 \% \mathrm{HA}$, respectively. The increase in FSen is expected with the progression of the annual forage's reproductive cycle. Possibly, increasing stem mass and pseudostem height during pre-flowering leads to a higher shading condition in the canopy and shading elevation can contribute to increases in the senescence rate (CONFORTIN et al., 2009).

There was no interaction of $\mathrm{HA} \times$ phenological stages for leaf blades intake in \% $\mathrm{BW}$ $(\mathrm{P}=0.6161)$, being higher $(3.34 \% \mathrm{BW}, \mathrm{P}=0.0318)$ in the $12 \% \mathrm{HA}$ and lower in the 6 and $9 \%$ HA $(1.84 \%$ $\mathrm{BW})$, the latter two not differing from each other. Leaf blade intake correlated highly and positively with LBS ( $\mathrm{r}=0.87 ; \mathrm{P}<0.0001$ ), which is consistent with the fact that leaves are the structures preferentially consumed by animals and are of better nutritional quality (BRATTI et al., 2009). The reduction in leaf blade intake in the $6 \%$ and $9 \%$ HA relative to the $12 \%$ HA was $52.1 \%$. Forage intake is the main factor that influences the productivity of grazing systems (ELOY et al., 2014) and the greater intake of leaf blades in a given HA may have greater importance in the definition of management strategies and may be useful in decision making in livestock systems.
There was no interaction of $\mathrm{HA} \times$ phenological stages in terms of the actual efficiency and potential use of ryegrass and in terms of net balance $(\mathrm{P}>0.1)$. The actual pasture use efficiency (APUE) reflects the FIn in proportion to the flow of leaf blades and these flows were not changed by the different HA. The APUE (1.23) remained unchanged in the HA $(\mathrm{P}=0.6567)$. The APUE was changed with the progression of the ryegrass phenological stage $(\mathrm{P}=0.0340)$. The APUE, at the vegetative stage, was 1.11 , which means that leaf blades that were growing were consumed by lambs in entirety, creating a deficit of 0.11 . However, the passage from the vegetative stage to the pre-flowering caused the APUE (1.35) to decrease by $17 \%$, evidencing a greater difficulty of the lambs to obtain leaf blades for intake.

Potential pasture utilization efficiency (PPUE) was similar among all HA (-0.082; $\mathrm{P}=0.3456)$. Possibly, the negative potential efficiency occurred due to the increase of in FSen as the phenological stage progressed, since in the vegetative stage, the potential efficiency was 0.03 different from that observed during pre-flowering $(0.19 ; \mathrm{P}=0.0659)$. Considering that PPUE is defined as the proportion of forage that can be consumed by an animal, if the canopy is maintained at equilibrium (LOUAULT et al., 1997), in the vegetative stage, a greater proportion of leaf blades was available for intake by lambs, before leaf senescence.

The net balance (-61.9 kg DM of leafblades/ ha/day) was similar in all HA (Figure 1, $\mathrm{P}=0.1194$ ) and phenological stages of ryegrass $(\mathrm{P}=0.4473)$. This knowledge of the growth and senescence processes 
serves to balance the defoliation process to obtain better control of forage availability (PONTES et al., 2004). The negative balance is because of the fact that FGro was, on average, $48 \%$ lower than the sum of FIn and FSen. The negative balance is an indication that the forage consumed is also composed of pseudostems and the participation of this structural component in the canopy was about $35 \%$ in the forage mass.

\section{CONCLUSION}

Ryegrass pastures managed with herbage allowances between 6 and $12 \mathrm{~kg}$ of DM/100 kg of body weight do not suffer changes in growth flows and leaf blade intake patterns and in the potential efficiencies and actual pasture use efficiency. These variables are negatively affected by structural changes caused by the progression of ryegrass phenological stages. Thus, ryegrass can be managed with herbage allowances in the range of 6 to $12 \%$.

\section{DECLARATION OF CONFLICT OF INTERESTS}

The authors declare no conflict of interest. The founding sponsors had no role in the design of the study; in the collection, analyses, or interpretation of data; in the writing of the manuscript, and in the decision to publish the results.

\section{AUTHORS' CONTRIBUTIONS} of the article.

All authors contributed equally to the production

\section{REFERENCES}

BRATTI L. F.S. et al. Comportamento ingestivo de caprinos em pastagem de azevém e aveia-preta em cultivo puro e consorciado. Ciência Animal Brasileira, v.10, p.397-405, 2009. Available from: $<$ https://www.revistas.ufg.br/vet/article/view/548/4830>. Accessed: Sep. $18,2018$.

CAUDURO, G.F. et al. Fluxo de biomassa aérea em azevém anual manejado sob duas intensidades e dois métodos de pastejo. Revista Brasileira de Zootecnia, v.36, n.2, p.282290, 2007. Available from: <http://www.scielo.br/pdf/rbz/ v36n2/03.pdf>. Accessed: Sep. 18, 2018. doi: 10.1590/S151635982007000200003 .

CONFORTIN, A.C.C. et al. Fluxo de tecido foliar em azevém anual manejado sob três intensidades de pastejo.Ciência Rural, v.39, n.4, p.1193-1199, 2009. Available from: <http://www.scielo. br/pdf/cr/v39n4/a178cr913.pdf>. Accessed: Sep. 18, 2018. doi: 10.1590/S0103-84782009005000072.

CONFORTIN, A.C.C. et al. Morfogênese e estrutura de azevém anual submetido a três intensidades de pastejo. Acta Scientiarum. Animal Sciences, v.32, n.4, p.385-391, 2010. Available from: $<$ http://periodicos.uem.br/ojs/index.php/ActaSciAnimSci/ article/view/8657/0>. Accessed: Sep. 17, 2018. doi: 10.4025/ actascianimsci.v32i4.8657.

ELOY, L R. et al. Consumo de forragem por novilhas de corte recebendo farelo de arroz com e sem ionóforo. Ciência Rural, v.44, n.7, p.1223-1228, 2014. Available from: <http://www.scielo. br/pdf/cr/v44n7/0103-8478-cr-44-07-01223.pdf>. Accessed: Sep. 18, 2018. doi: 10.15901/0103-8478.cr20131135.

LOUAULT, F. et al. Efficiencies of ryegrass and white clover herbage utilization in mixtures continuously grazed by sheep. Grass and Forage Science, p.388-400, 1997. Available from: <https://onlinelibrary.wiley. com/doi/pdf/10.1111/j.1365-2494.1997.tb02371.x>. Accessed: Sep. 16, 2018. doi: 10.1111/j.1365-2494.1997.tb02371.x.

MOORE, K. J. et al. Describing and quantifying growth stages of perennial forage grasses. Agronomy \& Horticulture, v.83, p.1073-1077, 1991. Available from: <http://www.scielo.br/pdf/cr/ v40n6/a612cr1121.pdf $>$. Accessed: Feb. 07, 2019.

PONTES, L.S. et al. Fluxo de biomassa em pastagem de azevém anual (Lolium multiflorum Lam.) manejada em diferentes alturas. Revista Brasileira de Zootecnia, v.33, n.3, p.529-537, 2004. Available from: <http://www.scielo.br/pdf/rbz/v33n3/21474.pdf $>$. Accessed: Sep. 18, 2018. doi: 10.1590/35982004000.300002.

SALVADOR, P. R. et al. Fluxos de tecidos foliares em papuã sob pastejo de bezerras de corte em diferentes frequências de suplementação. Revista Brasileira de Saúde e Produção animal, v.15, n.4, p.835-845, 2014. Available from: <http://revistas.ufba.br/ index.php/rbspa/article /view/3113/1637>. Accessed: Feb. 07, 2019.

SALVADOR, P. R. et al. Farelo de arroz integral para bezerras de corte em pastejo de Papuã. Boletim da Indústria Animal, v.73, n.3, p.252-259, 2016. Available from: <http://iz.sp.gov.br/ pdfsbia/1475175636.pdf $>$. Accessed: Feb. 07, 2019.

SBRISSIA, A.F.; DA SILVA, S.C. Compensação tamanho/densidade populacional de perfilhos em pastos de capim-marandu. Revista Brasileira de Zootecnia, v.37, n.1, p.35-47, 2008. Available from: $<$ http://www.scielo.br/pdf/rbz/v37n1/v37n1a05.pdf $>$. Accessed: Feb. 07, 2019. doi: 10.1590/S1516-35982008000100005.

SILVA, M.F. et al. Leaf tissue flows in ryegrass managed under different stocking rates. Acta Scientiarum: Animal Sciences, v.37, n.2, p.115-121, 2015. Available from: <http://www.scielo. br/pdf/asas/v37n2/1807-8672-asas-37-02-00115.pdf $>$. Accessed: Sep. 18, 2018. doi: 10.4025/actascianimsci.v372.24898.

PENA, K. S. etal. Características morfogênicas, estruturais e acúmulo de forragem do capimtanzânia submetido a duas alturas e três intervalos de corte. Revista Brasileira de Zootecnia, v.38, n.11, p.2127-2136, 2009. Available from: <http://www.scielo.br/pdf/rbz/v38n11/a09v3811.pdf> Accessed: Feb. 08, 2019. doi: 10.1590/S1516-35982009001100009.

SKONIESKI, F. R. et al. Composição botânica e estrutural e valor nutricional de pastagens de azevém consorciadas.Revista Brasileira de Zootecnia, v.40, n.3, p.550-556, 2011. Available from: <http://www.scielo.br/pdf/rbz/v40n3/12.pdf $>$. Accessed: Feb. 07, 2019. doi: 10.1590/S1516-359820110003000.

SOLLENBERGER, L. E. et al. Reporting forage allowance in grazing experiments.Crop Science v.45, p.896-900, 2005. Available from: $<$ https://dl.sciencesocieties.org/publications $/ \mathrm{cs} / \mathrm{ab}$ stracts/45/3/0896?access $=0 \&$ view $=$ pdf $>$. Accessed: Feb. 07, 2018. doi: 10.2135/cropsci2004.0216. 